\title{
Biological Reduction of COD and Sulphate by SRB in Anaerobic Moving Bed Biofilm Reactor under High Metal Loading Conditions
}

\author{
Enoch A. Akinpelu, Elvis Fosso-Kankeu, Frans Waanders and Seteno K. Ntwampe
}

\begin{abstract}
The performance of an anaerobic moving bed biofilm reactor (MBBR) containing AnoxKaldnes ${ }^{\mathrm{TM}} \mathrm{K} 5$ model for the treatment of raw acid mine drainage (AMD) was investigated for the reduction of sulphate and chemical oxygen demand using a consortium of sulphate reducing bacteria (SRB) dominated by Proteobacteria. The MBBR was enriched for 4 weeks, followed by introduction of raw AMD and sampling at intervals for 7 weeks. Maximum removal efficiency of COD was $99 \%$ followed by $75 \%$ sulphate reduction. The results showed that the bio-carrier is more suited for the COD reduction.
\end{abstract}

Keywords - Acid mine drainage; Chemical oxygen demand; Heavy metals; moving bed biofilm reactor; Sulphate reducing bacteria.

\section{INTRODUCTION}

The rapid development of minerals industry in South Africa has led to increase in volumes of mining wastewater containing sulphate and heavy metals generated [1-5]. The discharge of poorly treated and/or untreated wastewater is a major threat to the water bodies and as a result, the human health and the environment at large are susceptible to diverse diseases and sickness. The acid mine drainage (AMD) generated causes acidification and contamination of both surface and underground water with heavy metals [6-11]. The presence of sulphate increases the salinity of receiving water bodies and consequently reduces the availability of potable water [12].

Recently, anaerobic biological technology has been deployed for the treatment of sulphate containing wastewater, at both laboratory and full-scale such as Thiopaq ${ }^{\circledR}$ technology [13]. During anaerobic biological sulphate reduction, sulphide and bicarbonate are produced by sulphate reducing bacteria (SRB) in the presence of an appropriate electron donor and carbon source. The bicarbonate neutralises the acidity while dissolved metals are precipitated as metal sulphides, which can be

Manuscript received October 03, 2018. This work is based on the research supported wholly by the National Research Foundation of South Africa (Grant Number: 111993).

E. A. Akinpelu is with the Water Pollution Monitoring and Remediation Initiatives Research Group and the School of Chemical and Minerals Engineering, North-West University, South Africa.

E. Fosso-Kankeu is with the Water Pollution Monitoring and Remediation Initiatives Research Group and the School of Chemical and Minerals Engineering, North-West University, South Africa.

F. Waanders is with the School of Chemical and Minerals Engineering, North-West University, South Africa.

S. K. Ntwampe is with the Department of Biotechnology, Cape Peninsula University of Technology, South Africa. separately removed based on the solubility of different metal sulphides at different $\mathrm{pH}[13,14]$.

In addition to the high concentration of pollutants - sulphate and heavy metals in AMD, there is a challenge of high chemical oxygen demand (COD) that accompanies the wastewater treatment. The high COD can be used up during methanogenic activity but this will compete with the carbon source meant for SRB proliferation, hence, the need for bio-carrier - a proven COD removal technology $[15,16]$. The moving-bed biofilm reactor (MBBR) is a vastly efficient technology for the treatment of wastewater due to its relatively low footprint. The prolonged retention time of biomass within the reactors is a major feature through bonding of microorganisms onto the surface of bio-carriers that are maintained in suspension via mechanical stirring (anaerobic) or aeration (aerobic). Sequential changes of the attached microbial community will lead to the development of an established biofilm [17].

Therefore, the objective of this research work was to assess the performance of consortium of sulphate reducing bacteria in an MBBR, to determine both the sulphate and COD reduction rate, under high metal loading conditions.

\section{MATERIALS AND METHODS}

\section{A. AMD Collection, Isolation and Growth Media for SRB}

Acid mine drainage sample was collected from coal mining site in Mpumalanga Province, South Africa using standard sampling procedure (EPA 2007). The AMD sample was screened for the removal of big particles and stored at $4^{\circ} \mathrm{C}$. The AMD temperature was $20^{\circ} \mathrm{C}$ with low $\mathrm{pH}$ (2.98) and high redox potential $(229.5 \mathrm{mV})$. The concentration of metal ions in the AMD samples were measured using the inductively coupled plasma optical emission spectrometer (ICP-OES) (ICP Expert II, Agilent Technologies 720 ICP-OES). A COD and Multiparameter Bench Photometer HI 83099 (Hanna Instruments Inc., USA) was used to measure both the COD and sulphate $\left(\mathrm{SO}_{4}^{2-}\right)$ concentration in the AMD samples.

A sterile $500 \mathrm{~mL}$ bioreactor containing sterilised $400 \mathrm{~mL}$ modified Postgate isolation media [18] was inoculated with $20 \%$ (v/v) AMD. The composition of Postgate isolation media was (g/L): $\mathrm{Na}_{2} \mathrm{SO}_{4} 1.0 ; \mathrm{CaCl}_{2} .2 \mathrm{H}_{2} \mathrm{O} 0.1 ; \mathrm{MgSO}_{4} 2.0 ; \mathrm{KH}_{2} \mathrm{PO}_{4}$ $0.5 ; \mathrm{NH}_{4} \mathrm{Cl} 1.0$; yeast extract $1.0 ;$ ascorbic acid 0.1; thioglycollic acid $0.1 ; \mathrm{FeSO}_{4} \cdot 7 \mathrm{H}_{2} \mathrm{O} 0.5 ; \mathrm{NaCl} 26$; sodium lactate $5 \mathrm{~mL}$; and $\mathrm{pH} 7-7.5$. All reagents were analytical grade. The bioreactor was kept in anaerobic conditions for the growth 
of SRB for 7 days at $35^{\circ} \mathrm{C}$ till the colour of the media changed to blackish grey. Subsequently, $20 \%$ (v/v) inoculum containing several isolates were transferred into $400 \mathrm{~mL}$ Postgate isolation media in a new sterile $500 \mathrm{~mL}$ bioreactor. The procedure was in triplicate.

\section{B. Experimental Set-up}

The anaerobic moving-bed biofilm reactor experiments were conducted in a $1.2 \mathrm{~L}$ working volume glass reactor fitted with an overhead stirrer. The high density polyethylene (HDPE) AnoxKaldnes ${ }^{\mathrm{TM}} \mathrm{K} 5$ bio-carriers were used, which were about $15 \%$ of the working volume. The bio-carrier has a length of 3.5 $\mathrm{mm}$, diameter of $25 \mathrm{~mm}$ and specific surface area of $800 \mathrm{~m}^{2} / \mathrm{m}^{3}$. The reactor containing $800 \mathrm{~mL}$ Postgate isolation media was initiated with $10 \%$ inoculum at $35^{\circ} \mathrm{C}$ and $\mathrm{pH}$ around 7 for 4 weeks with $70 \%$ of the medium being drawn weekly and replaced with fresh Postgate isolation media. The reactor was purged with nitrogen gas to displace dissolved oxygen. To prevent methanogenic activity, sodium bromoethane sulphonate $(3.2 \mathrm{~g} / \mathrm{L})$ was added to the culture during enrichment (4 weeks). After establishing viable microbial population, raw AMD (10\% $\mathrm{v} / \mathrm{v}$ ) was introduced to the MBBR operated in continuous mode. The MBBR was kept in the continuous mode for 7 weeks and sampled at predetermined intervals. The microbial growth was observed in a GENESYS ${ }^{\mathrm{TM}}$ 10S UV-Vis spectrophotometer (Thermo Fisher Scientific ${ }^{\mathrm{TM}}$, Waltham, MA, USA) based on optical density at a wavelength of $600 \mathrm{~nm}$. The control experiment was not inoculated with SRB. All measurements were in triplicate.

The removal efficiency was estimated based on the difference between the initial and final concentrations as follows:

$$
\text { Removal }(\%)=\left(\frac{C_{i}-C_{f}}{C_{i}}\right) \times 100
$$

Where $C_{i}$ and $C_{f}$ are initial and final concentrations $(\mathrm{mg} / \mathrm{L})$ in the raw and treated AMD, respectively.

\section{RESULTS AND DISCUSSION}

\section{A. Anaerobic MBBR performance}

The reactor was inoculated with Postgate isolation media for 4 weeks to achieve sufficient concentration of attached biomass in the MBBR. This period is referred to as an enrichment stage, during which the microorganisms colonised the bio-carrier at an initial loading rate of $426 \mathrm{mg} \mathrm{COD} / \mathrm{L}$. At the end of enrichment stage, the COD had risen to $1740 \mathrm{mg} \mathrm{COD} / \mathrm{L}$. With the introduction of raw AMD into the MBBR, COD removal was low at the early stage (between $1-3$ weeks) while the sulphate reduction was very high which was a result of inhibition of methanogenic activities. However, after $4^{\text {th }}$ week, there was consistent increase in COD removal efficiency up to $99 \%$ at the end of $7^{\text {th }}$ week. This can be traced to the combined effect of gradual decrease in available sodium bromoethane sulphonate in the reactor which allows methanogenic activity to proceed as well as the impact of the bio-carrier [15, 19]. Previous studies have shown that anaerobic MBBR plays a major role in the COD removal $[16,20]$. Chen et al [16] reported a total COD removal efficiency of $95 \%$ in the treatment of a landfill leachate even though there were some fluctuations in the performance of the MBBR due to varying operating conditions. Similarly, Bassin et al [15] observed above 95\% COD removal efficiency in the assessment of two different bio-carriers (AnoxKaldnes ${ }^{\mathrm{TM}}$ $\mathrm{K} 1$ and Mutag BioChip ${ }^{\mathrm{TM}}$ ). The higher theoretical surface area of AnoxKaldnes ${ }^{\mathrm{TM}} \mathrm{K} 5 \quad\left(800 \mathrm{~m}^{2} / \mathrm{m}^{3}\right)$ compared to AnoxKaldnes ${ }^{\mathrm{TM}} \mathrm{K} 1\left(500 \mathrm{~m}^{2} / \mathrm{m}^{3}\right)$, which provides effective area for biofilm growth, may have contributed to the higher COD removal observed in this study. In addition, MBBR often offers a relatively low amount of suspended solids in the effluent, when there is complete mixing of contaminants, sludge and biofilm, with less diffusion limitation, which benefits COD removal [21].

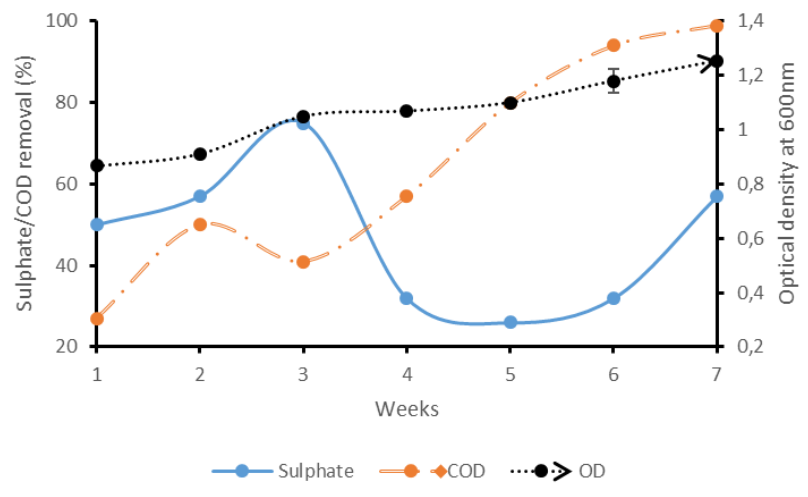

Fig. 1. Microbial growth with COD and Sulphate reduction in the anaerobic MBBR system.

Figure 1 shows the results of COD and sulphate reduction, including the microbial growth. The MBBR showed a maximum sulphate reduction efficiency of $75 \%$ after 3 weeks of continuous operation. The lower sulphate reduction observed between $4^{\text {th }}$ to $7^{\text {th }}$ week could be a combined effect of lower carbon source and high concentration) of heavy metals in raw AMD, including increased methanogenic activity, as shown by the higher COD reduction. The metagenomics analysis of the inoculum showed the dominance of Proteobacteria in the SRB as well as a few Firmicutes (our unpublished data). Different studies have reported varying results on biological sulphate reduction in AMD (70\% to 98\%), depending on reactor configuration and other process parameters. Greben et al [22] analysis showed a sulphate reduction of $93 \%$ using ethanol as carbon source in a single-stage anaerobic reactor while an improvement from $27 \%$ to $80 \%$ sulphate reduction was reported after augmentation with SRB consortium in an anaerobic biofilm reactor [23]. The higher residual sulphate concentration in this study can be attributed to the low reduction rate owing to the competition from the heavy metals in the raw AMD, including higher initial sulphate $(8080 \mathrm{mg} / \mathrm{L})$ and heavy metal concentrations in the raw AMD.

\section{B. Redox potential and $\mathrm{pH}$}

As expected, a sharp drop in $\mathrm{pH}$ was observed after enrichment stage, when raw AMD at a lower $\mathrm{pH}$ was introduced into the MBBR, and steadily increased. Conversely, increase in redox potential (Eh) was observed due to introduction of AMD at a higher Eh into the reactor, and steadily decreased. The $\mathrm{pH}$ and $\mathrm{Eh}$ of the sample from the bioreactor reached 5.23 and $120.3 \mathrm{mV}$ in 7 weeks, respectively, while it remained constant 
in the control experiment. The $\mathrm{pH}$ and Eh profiles are shown in Fig. 2. The steady decrease in Eh and increase in $\mathrm{pH}$ was suggestive of an acclimatisation period by the SRB consortium to the new conditions. Similar increase in $\mathrm{pH}$ with decrease in Eh were reported in the treatment of AMD by SRB [24,25].

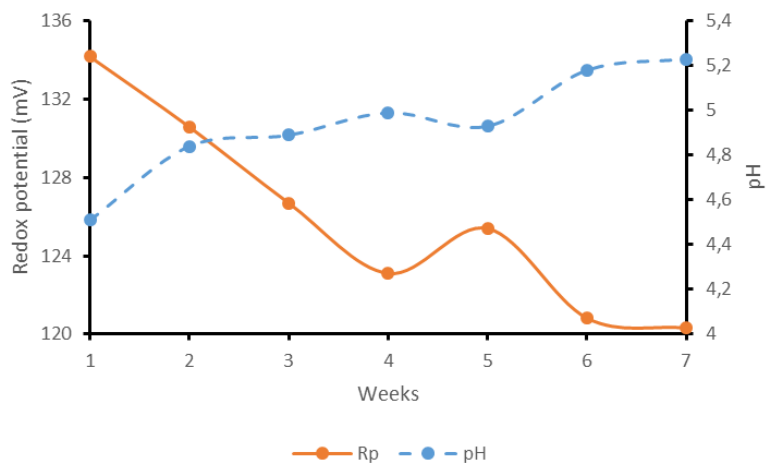

Fig. 2. Redox potential and $\mathrm{pH}$ of the SRB consortium in the anaerobic MBBR system.

\section{Heavy metal removal}

The removal efficiency of metal ions in the treated AMD sample was measured using the inductively coupled plasma optical emission spectrometer (ICP-OES) (ICP Expert II, Agilent Technologies 720 ICP-OES) is shown in Fig. 3. The results showed significant reduction in concentrations of $\mathrm{Al}^{3+}$, $\mathrm{Co}^{3+}, \mathrm{Sr}^{2+}, \mathrm{Mn}^{2+}, \mathrm{Ca}^{2+}, \mathrm{Cd}^{2+}, \mathrm{V}^{5+}$ and $\mathrm{Ni}^{2+}$ as $95 \%, 88 \%, 88 \%$, $87 \%, 78 \%, 77 \%, 77 \%$ and $73 \%$, respectively, by the SRB consortium. This is comparable to those reported by Jong and Parry (2003), whose report indicated above 75\% removal of $\mathrm{Ni}^{2+}$ by SRB in an anaerobic packed bed reactor, however, $\mathrm{Al}^{3+}$ and $\mathrm{Mg}^{2+}$ remained unchanged in their system. The higher heavy metal removal efficiency observed in the MBBR is a confirmation of the interaction between the SRB consortium and the facultative anaerobic Bacillus cereus as seen in previous studies [26,27]. Conversely, the percent reduction of copper and magnesium in the AMD was very low; $12 \%$ and $14 \%$, respectively. The metal removal can be attributed to the precipitation of insoluble metal sulphides resulting from the sulphides produced by the biological activities of the SRB.

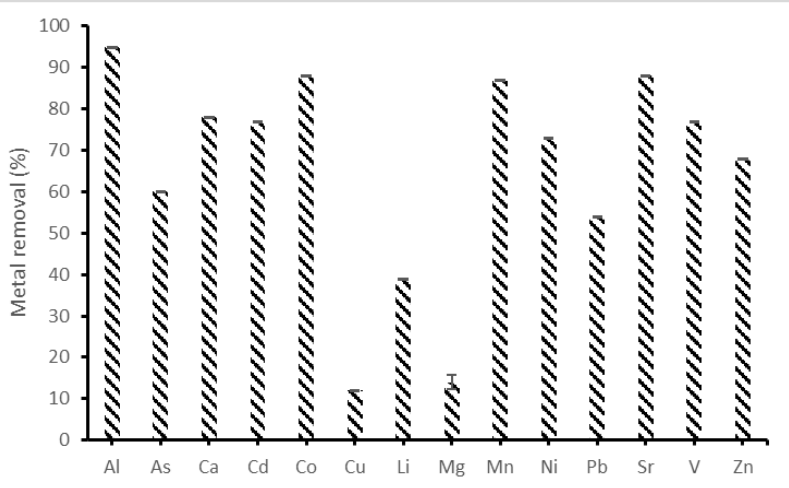

Fig. 3: Metal removal in the anaerobic MBBR system.

\section{CONCLUSION}

This study showed microbial reduction of sulphate and COD, as well as significant precipitation of $\mathrm{Al}^{3+}, \mathrm{Co}^{3+}, \mathrm{Sr}^{2+}, \mathrm{Mn}^{2+}$, $\mathrm{Ca}^{2+}, \mathrm{Cd}^{2+}, \mathrm{V}^{5+}$ and $\mathrm{Ni}^{2+}$ in raw AMD by a consortium of SRB in an anaerobic MBBR containing AnoxKaldnes ${ }^{\mathrm{TM}}$ K5 bio-carriers. After acclimatisation period, the early stage of the process showed $75 \%$ reduction of sulphate due to inhibition of methanogenic activity. The bio-carrier played a major role in the removal of COD (99\%) due to methanogenesis at the later stage of the process. The results indicated that direct feeding of raw AMD without pre-neutralisation offers an advantage for in situ implementation of AMD treatment in an anaerobic MBBR.

\section{ACKNOWLEDGMENT}

The authors appreciate Veolia Water Technologies AnoxKaldnes, Sweden for the free supply of bio-carriers.

\section{REFERENCES}

[1] E. Fosso-Kankeu, A. Mulaba-Bafubiandi, B.B. Mamba, T.G. Barnard, Mitigation of $\mathrm{Ca}, \mathrm{Fe}$, and $\mathrm{Mg}$ loads in surface waters around mining areas using indigenous microorganism strains. Journal of Physics and Chemistry of the Earth, Vol. 34, pp. 825-829, 2009.

https://doi.org/10.1016/j.pce.2009.07.005

[2] E. Fosso-Kankeu, A. Mulaba-Bafubiandi, B.B. Mamba, L. Marjanovic, T.G. Barnard, A comprehensive study of physical and physiological parameters that affect biosorption of metal pollutants from aqueous solutions. Journal of Physics and Chemistry of the Earth, Vol. 35, pp. 672-678, 2010.

https://doi.org/10.1016/j.pce.2010.07.008

[3] E. Fosso-Kankeu, A.F. Mulaba-Bafubiandi, B.B. Mamba and T.G. Barnard, Prediction of metal-adsorption behaviour in the remediation of water contamination using indigenous microorganisms. Journal of Environmental Management. Vol. 92, no. 10, pp. 2786-2793, 2011. https://doi.org/10.1016/j.jenvman.2011.06.025

[4] H. Mittal, E. Fosso-Kankeu, Shivani B. Mishra, Ajay K. Mishra, Biosorption potential of Gum ghatti-g-poly (acrylic acid) and susceptibility to biodegradation by B. subtilis. International Journal of Biological Macromolecules. Vol. 62, pp. 370-378, 2013. https://doi.org/10.1016/j.ijbiomac.2013.09.023

[5] E. Fosso-Kankeu, A.F. Mulaba-Bafubiandi, T.G. Barnard, Establishing suitable conditions for metals recovery from metal saturated Bacillaceae bacterium using experimental design. International Biodeterioration and Biodegradation. Vol. 86, pp. 218-224, 2014. https://doi.org/10.1016/j.ibiod.2013.09.022

[6] A. Manyatshe, E. Fosso-Kankeu, D. van der Berg, N. Lemmer, F. Waanders, H. Tutu, Metal retention potential of sediment and water quality in the Mooi River, South Africa. Desalination and Water Treatment. doi: 10.5004/dwt2017.20222. 2017.

[7] E. Fosso-Kankeu, A. Manyatshe, F. Waanders, Mobility potential of metals in acid mine drainage occurring in the Highveld area of Mpumalanga Province in South Africa: Implication of sediments and efflorescent crusts. International Biodeterioration and Biodegradation. Vol. 119, pp. 661-670, 2017.

https://doi.org/10.1016/j.ibiod.2016.09.018

[8] E. Fosso-Kankeu, A. Manyatshe, A. Munyai, F. Waanders, AMD formation and dispersion of inorganic pollutants along the main stream in a mining area. In: Drebenstedt, C. \& Paul, M.: IMWA 2016 - Mining Meets Water - Conflicts and Solutions. - p. 391 - 397; Freiberg/Germany (TU Bergakademie Freiberg). 2016.

[9] E. Fosso-Kankeu, Investigation of the oxidation rate of sediments from AMD using humidity cell test. International Conference on Advances in Science, Engineering, Technology and Natural Resources (ICASETNR-16) Nov. 24-25, 2016, Parys - South Africa. ISBN: 978-93-84468-79-8. 2016.

[10] E. Fosso-Kankeu and J. Redelinghuys, Bacterial ecology of biofilms sustaining pollution by acid mine drainage near mining areas in Mpumalanga Province - South Africa. $11^{\text {th }}$ ICARD/IMWA/MWD Conference "Risk to Opportunity". 10-14 September 2018 Pretoria, South Africa. C. Wolkersdorfer, L. Sartz, A. Weber, J. Burgess, G. Tremblay.ISBN: 978-0-620-80650-3 Vol 1 (2 volumes). 2018. 
[11] O. O. Oyekola, R. P. van Hille, and S. T. L. Harrison, "Kinetic analysis of biological sulphate reduction using lactate as carbon source and electron donor: Effect of sulphate concentration," Chemical Engineering Science, vol. 65 , no. 16, pp. 4771-4781, August, 2010. https://doi.org/10.1016/j.ces.2010.05.014

[12] W. Pulles, D. Howie, D. Otto, and J. Easton, A manual on mine water treatment and management practices in South Africa, Report No. TT 80/96, Water Research Commission, Pretoria, 1995.

[13] J. Boonstra, R. van Lier, G. Janssen, H. Dijkman, and C. J. N. Buisman, "Biological treatment of acid mine drainage," Biohydrometallurgy and the Environment Toward the Mining of the 21st Century - Proceedings of the International Biohydrometallurgy Symposium, R. Amils and A. Ballester, eds., pp. 559-567, Amsterdam: Elsevier, 1999.

[14] W. J. Drury, "Treatment of acid mine drainage with anaerobic solid-substrate reactors," Water Environment Research, vol. 71, no. 6, pp. 1244-1250, 1999. https://doi.org/10.2175/106143096X122375

[15] J. P. Bassin, I. N. Dias, S. M. S. Cao, E. Senra, Y. Laranjeira, and M. Dezotti, "Effect of increasing organic loading rates on the performance of moving-bed biofilm reactors filled with different support media: Assessing the activity of suspended and attached biomass fractions," Process Safety and Environmental Protection, vol. 100, pp. 131-141, March, 2016.

https://doi.org/10.1016/j.psep.2016.01.007

[16] S. Chen, D. Sun, and J.-S. Chung, "Simultaneous removal of COD and ammonium from landfill leachate using an anaerobic-aerobic moving-bed biofilm reactor system," Waste Management, vol. 28, no. 2, pp. 339-346, January, 2008. https://doi.org/10.1016/j.wasman.2007.01.004

[17] K. Biswas, M. W. Taylor, and S. J. Turner, "dsrAB-based analysis of sulphate-reducing bacteria in moving bed biofilm reactor (MBBR) wastewater treatment plants," Applied Microbiology and Biotechnology, vol. 98, no. 16, pp. 7211-7222, August, 2014 https://doi.org/10.1007/s00253-014-5769-5

[18] J. Postgate, The sulphate-reducing bacteria, Cambridge: Cambridge University Press, 1984.

[19] W. Miran, J. Jang, M. Nawaz, A. Shahzad, S. E. Jeong, C. O. Jeon, and D. S. Lee, "Mixed sulfate-reducing bacteria-enriched microbial fuel cells for the treatment of wastewater containing copper," Chemosphere, vol. 189, pp. 134-142, December, 2017 https://doi.org/10.1016/j.chemosphere.2017.09.048

[20] S. Chai, L. Gao, and J. Cai, "Sulphate reduction optimization by sulphate-reducing bacteria in a glucose-fed anaerobic moving bed biofilm reactor," Energy Educ. Sci. Technol. Part A, vol. 29, pp. 201-208, 2012.

[21] H. Ødegaard, M. Cimbritz, M. Christensson, and C. P. Dahl, "Separation of Biomass From Moving Bed Biofilm Reactors (MBBRs)," Proceedings of the Water Environment Federation, vol. 2010, no. 7, pp. 212-233, 2010. https://doi.org/10.2175/193864710798208368

[22] H. Greben, J. Maree, Y. Singmin, and S. Mnqanqeni, "Biological sulphate removal from acid mine effluent using ethanol as carbon and energy source," Water Science and Technology, vol. 42, no. 3-4, pp. 339-344, 2000 https://doi.org/10.2166/wst.2000.0400

[23] S. V. Mohan, N. C. Rao, K. K. Prasad, and P. N. Sarma, "Bioaugmentation of an anaerobic sequencing batch biofilm reactor (AnSBBR) with immobilized sulphate reducing bacteria (SRB) for the treatment of sulphate bearing chemical wastewater," Process Biochemistry, vol. 40, no. 8, pp. 2849-2857, July, 2005. https://doi.org/10.1016/j.procbio.2004.12.027

[24] Z. Liu, L. Li, Z. Li, and X. Tian, "Removal of sulfate and heavy metals by sulfate-reducing bacteria in an expanded granular sludge bed reactor," Environmental Technology, vol. 39, no. 14, pp. 1814-1822, July, 2018. https://doi.org/10.1080/09593330.2017.1340347

[25] S. D. Kim, J. J. KilbaneII, and D. K. CHA, "Prevention of Acid Mine Drainage by Sulfate Reducing Bacteria: Organic Substrate Addition to Mine Waste Piles," Environmental Engineering Science, vol. 16, no. 2, pp. 139-145, 1999. https://doi.org/10.1089/ees.1999.16.139

[26] M. Wu, X. Xu, Q. Zhao, and Z. Wang, "Simultaneous removal of heavy metals and biodegradation of organic matter with sediment microbial fuel cells," RSC Advances, vol. 7, no. 84, pp. 53433-53438, 2017.
https://doi.org/10.1039/C7RA11103G

[27] B. Christensen, M. Laake, and T. Lien, "Treatment of acid mine water by sulfate-reducing bacteria; results from a bench scale experiment," Water Research, vol. 30, no. 7, pp. 1617-1624, July, 1996. https://doi.org/10.1016/0043-1354(96)00049-8

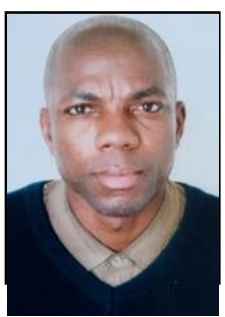

Enoch A. Akinpelu is a postdoctoral fellow in the School of Chemical and Minerals Engineering, North-West University, Potchefstroom Campus, South Africa. He holds a doctorate degree in Chemical Engineering and has published journal articles, book chapters as well as conference proceedings. 